\title{
Protein Synthesis in a Cell Free Human Reticulocyte System: Ribosome Function in Thalassemia *
}

\author{
Arthur Bank $\dagger$ and Paul A. Marks \\ (From the Department of Medicine, Columbia University College of Physicians and Surgeons, \\ New York, N. Y.)
}

Thalassemia major is a genetically determined anemia of man in which the major biochemical defect is a selective decrease in the synthesis of hemoglobin A (1). Elucidation of the molecular basis of this defect is of considerable importance since it should provide a better understanding of thalassemia as a disease entity and may give new information concerning the regulation of protein synthesis in mammalian cells.

Several possible defects have been postulated to account for the decrease in hemoglobin A formation in thalassemia. Thus, it was suggested that thalassemia may be associated with the formation of a structurally abnormal hemoglobin that is made at a rate slower than normal $(2,3)$. However, analysis of the amino acid content of individual tryptic peptides of hemoglobin from subjects with thalassemia has, as yet, revealed no structural abnormalities (4). Alternatively, it was proposed (4-6) that in thalassemia the defect in protein synthesis involved a selective impairment in the capacity of the ribosome-messenger ribonucleic acid (mRNA) complex to form structurally normal hemoglobin $A$. In the present investigation, a cell free system for protein synthesis has been developed from human reticulocytes and this latter hypothesis tested further by comparing the capacity for amino acid incorporation of ribosome fractions prepared from erythroid cells of thalassemic and nonthalassemic subjects.

* Submitted for publication August 18, 1965 ; accepted November 22, 1965.

Supported in part by U. S. Public Health Service grants CY02332 and GM07368, National Science Foundation grant GB-1817, and a grant from the Cooley's Anemia Foundation.

These studies were presented in part at the annual meeting of the American Society of Hematology in Philadelphia on December 5-7, 1965.

† Trainee in hematology, supported by U. S. Public Health Service training program grant TI-AM5231.
The results of experiments reported here using the cell free system indicate that there is a marked defect in the capacity of the ribosome fraction prepared from reticulocytes of thalassemic patients to support the incorporation of amino acids into protein. This will be referred to as endogenous activity. In contrast to this markedly decreased endogenous activity, there is no significant impairment of the capacity of thalassemic ribosomes to support polyuridylic acid (poly U)-directed incorporation of phenylalanine.

\section{Methods}

a) Preparation of ribosomes and supernatants. Heparinized blood was obtained from 16 patients with thalassemia major, seven patients with sickle cell anemia, and five patients with other hemolytic anemias. None of the patients had been transfused for at least 1 month before the study. For the preparation of rabbit reticulocytes, blood was obtained from phenylhydrazine-treated rabbits according to procedures detailed elswhere (7). Ribosomes and supernatant solutions were prepared by a method similar to that described by Weisberger, Armentrout, and Wolfe (8). The blood cells were recovered from whole blood by centrifugation, washed with a solution containing $0.13 \mathrm{M} \mathrm{NaCl}, 0.005 \mathrm{M} \mathrm{KCl}$, and 0.0075 $\mathrm{M} \mathrm{MgCl}_{2}$, and lysed by mixing the cells with 4 vol of $0.002 \mathrm{M} \mathrm{MgCl}_{2}$ for 1 minute at $4^{\circ}$. One vol of a solution of $1.5 \mathrm{M}$ sucrose containing $0.15 \mathrm{M} \mathrm{KCl}$ was then added. Stroma and leukocytes were removed by centrifugation for 15 minutes at $15,000 \times g$. The supernate fraction was recovered and centrifuged for 2 hours at $150,000 \times g$. The resulting pellet containing ribosomes was rinsed with a solution containing $0.002 \mathrm{M} \mathrm{MgCl}_{2}, 0.017 \mathrm{M} \mathrm{KHCO}$, and $0.25 \mathrm{M}$ sucrose, and then resuspended in this solution and frozen at $-70^{\circ} \mathrm{C}$.

b) Analysis of ribosomes. Ribosome content is expressed as the optical density at $260 \mathrm{~m} \mu$ (OD 260) of ribosomes per $10^{10}$ reticulocytes. The total number of reticulocytes present per milliliter of blood was obtained by multiplying the red.cell count per milliliter by the per cent of the cells that were reticulocytes.

The sedimentation characteristics of ribosomes were analyzed by the technique of sucrose density gradient centrifugation (9). The per cent of the ribosomes that 
was polyribosomes was determined by planimetry of the curve of OD 260 obtained from the sedimentation pattern in the sucrose density gradients.

c) Conditions for incubation of intact cells. Intact cell incubations were performed as described previously (5). After 80 minutes of incubation, the cells were washed, lysed, and ribosomes prepared as described above. Amino acid incorporation is expressed as counts per minute per OD 260 unit of ribosomes. Amino acid incorporation by cells was referred to ribosome content of the incubated cells rather than cell count, protein concentration, or hemoglobin concentration, because this parameter was found to provide most reproducible results (10). In studies with whole reticulocytes, the rate of amino acid incorporation is expressed as counts per minute per OD 260 units of ribosomes per hour. The incorporation of amino acids into soluble protein by cells incubated under the present experimental conditions proceeds at a linear rate for at least 80 minutes (6). On the other hand, amino acid incorporation associated with ribosomes reaches a maximum within 5 minutes (6). Radioactivity associated with ribosomes is expressed as counts per minute per OD 260 of ribosomes and represents a capacity of the ribosomes to incorporate radioactivity. Radioactivity associated with the ribosome pellet was measured by using a portion of ribosomes resuspended in $0.002 \mathrm{M} \mathrm{MgCl}_{2}, 0.017 \mathrm{M} \mathrm{KHCO}$, and 0.25 $M$ sucrose.

d) Conditions for incubation of ribosomes in a cell free system. The cell free assay system for protein synthesis was similar to that described by Allen and Schweet (11). Each incubation mixture contained $5.35 \mu$ moles of Tris buffer at pH 7.5, $0.29 \mu$ mole ATP, $0.036 \mu$ mole guanosine triphosphate (GTP), $20 \mu \mathrm{g}$ pyruvate kinase (PK), 1.44 $\mu$ moles phosphoenol pyruvate (.PEP), $0.096 \mu$ mole 2-mercaptoethanol, $2.1 \mu$ moles magnesium chloride $\left(\mathrm{MgCl}_{\mathbf{2}}\right)$,

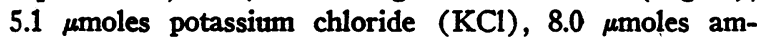
monium chloride $\left(\mathrm{NH}_{4} \mathrm{Cl}\right), 0.022 \mathrm{ml}$ of a mixture of 20 amino acids containing an average of $2.5 \mu$ moles per $\mathrm{ml}$ of each amino acid minus the radioactive amino acids, and 0.65 to 0.70 mumole radioactive amino acid- ${ }^{24} \mathrm{C}$ (specific activity of 200 to $500 \mu \mathrm{c}$ per $\mu$ mole), $0.05 \mathrm{ml}$ of supernate fraction (with an average hemoglobin concentration of 10 to $15 \mathrm{mg}$ per $\mathrm{ml}$ ), and 0.1 to $1.0 \mathrm{OD} 260$ of ribosomes in a final volume of $0.3 \mathrm{ml}$. In experiments with phenylalanine- ${ }^{14} \mathrm{C}, 13.2 \mu$ moles Tris buffer at $\mathrm{pH} 7.5$ was used and $100 \mu \mathrm{g}$ of poly $U$ added where indicated. The optimal magnesium ion $\left(\mathrm{Mg}^{++}\right)$concentration for poly U-directed amino acid incorporation was 12 mmoles per $\mathrm{L}$ compared with a $\mathrm{Mg}^{++}$optimum of 7 mmoles per $\mathrm{L}$ for the endogenous reaction. Similar observations have been reported for a cell free system prepared from rabbit reticulocytes (12) and for a system prepared from rat liver (13). Incubations were performed at $37^{\circ} \mathrm{C}$ for 90 minutes, and the reaction was stopped by the addition of $1 \mathrm{ml}$ of cold $7.5 \%$ trichloroacetic acid (TCA).

e) Determination of radioactivity. The TCA precipitates were washed once with $5 \%$ TCA, resuspended, heated at $90^{\circ} \mathrm{C}$ for 30 minutes, and filtered onto Millipore
TABLE I

Requirements in the cell free system for protein synthesis

\begin{tabular}{lcc}
\hline \multirow{2}{*}{ Additions } & \multicolumn{2}{c}{ Source of supernatant } \\
\cline { 2 - 3 } & Rabbit & Human \\
\hline & \multicolumn{2}{c}{ cpm per OD 260} \\
Complete system* & 1,850 & 1,965 \\
No ATP, GTP, PK, PEP $\dagger$ & 695 & 0 \\
No Mg+十 & 0 & 0 \\
No supernate fraction & 200 & 200 \\
No ribosomes & 414 & 320 \\
\hline
\end{tabular}

* Complete system is as detailed in Methods. Leucine${ }^{14} \mathrm{C}$, valine- ${ }^{14} \mathrm{C}$, and phenylalanine- ${ }^{14} \mathrm{C}$ were used in these experiments.

† GTP = guanosine triphosphate, $\mathrm{PK}=$ pyruvate $\mathrm{ki}$ nase, and $\mathrm{PEP}=$ phosphoenol pyruvate.

discs $2.5 \mathrm{~cm}$ in diameter. The Millipore discs were dissolved in $10 \mathrm{ml}$ of Bray's solution (14) containing $4 \%$ Cab-O-Sil ${ }^{1}$ (15) and counted in a liquid scintillation counter with an efficiency of $70 \%$. The radioactivity was corrected for background and is expressed as counts per minute rather than millimicromoles per liter of amino acid because in many experiments three radioactive amino acids with different specific activities were employed.

f) Statistical analysis. The methods used to evaluate the data statistically are those of Lindquist (16).

\section{Results}

a) Amino acid incorporation by intact reticulocytes. It has been previously reported that intact reticulocytes of subjects with thalassemia have a decreased capacity to incorporate leucine and valine into soluble protein $(6,17)$. In preliminary experiments with the subjects of the present study, this observation was confirmed. The incorporation of leucine plus valine associated with the ribosomes of reticulocytes from patients with thalassemia major averaged $156 \mathrm{cpm}$ per OD 260 of ribosomes compared with an average of $455 \mathrm{cpm}$ per OD 260 of ribosomes from cells of nonthalassemic subjects. Furthermore, the rate of incorporation of leucine plus valine into soluble protein was consistently lower in cells from thalassemic subjects compared to those from nonthalassemic subjects. The average rate for the cells of the thalassemic patients was $28,100 \mathrm{cpm}$ per OD 260 ribosomes per hour compared with $88,500 \mathrm{cpm}$ per OD 260 ribosomes per hour for the cells of nonthalassemic subjects. Incorporation increased linearly during the hour of incubation.

${ }^{1}$ G. L. Cabot, Boston, Mass. 
TABLE II

Endogenous amino acid-incorporating capacity of ribosomes prepared from cells of nonthalassemic and thalassemic subjects*

\begin{tabular}{ccc}
\hline & \multicolumn{2}{c}{ Source of supernatant fraction } \\
\cline { 2 - 3 } Subject & Rabbit & Human \\
\multicolumn{3}{c}{ cpm per OD 260} \\
S.C. & \multicolumn{3}{c}{1,850} & 1,965 \\
V.M. & 1,640 & 1,700 \\
A.C. & 2,530 & 1,660 \\
O.A. & 2,140 & 1,670 \\
K.N. & 4,370 & 4,615 \\
D.N. & 3,925 & \\
B.B. & 1,700 & \\
S.W. & 1,500 & \\
C.W. & 2,725 & \\
Average \pm SD & $2,487 \pm 970$ & $2,322 \pm 1,155$ \\
\multicolumn{3}{c}{ Thalassemic subjects } \\
M.D. & 225 & \\
I.J. & 238 & 180 \\
R.M. & 293 & 126 \\
N.G. & 980 & \\
T.D. & $<5$ & 485 \\
A.A. & $<50$ & $264 \pm 157$ \\
F.P. & 130 & \\
J.M. & $<50$ & \\
Average \pm SD & $255 \pm 280$ & \\
&
\end{tabular}

${ }^{*}$ Valine $-{ }^{14} \mathrm{C}$, leucine $-{ }^{14} \mathrm{C}$, and phenylalanine- ${ }^{14} \mathrm{C}$ were used in these experiments.

b) Characteristics of the cell free system. Maximal levels of amino acid incorporation into protein were dependent upon the presence of ATP, GTP, PEP, PK, $\mathrm{Mg}^{++}$, ribosomes, and supernatant fraction (Table I). Incorporation was directly proportional to the amount of ribosomes when 0.1 to $1.0 \mathrm{OD} 260$ of ribosomes was added. This proportionality to ribosomes was also observed when phenylalanine- ${ }^{14} \mathrm{C}$ incorporation was measured in the absence and presence of poly $U$.

The capacity to incorporate amino acids into protein employing supernatant fractions prepared from cells of rabbits and of human subjects was tested with the same human ribosomes. Of the supernatant fractions used, those obtained from cells of phenylhydrazine-treated rabbits with over $80 \%$ reticulocytes reproducibly gave the maximal levels of amino acid incorporation with a given ribosome preparation. With some supernatant fractions prepared from cells of human subjects, the level of incorporation of amino acids was similar to maximal levels achieved with the rabbit supernatant fractions; other human supernatants gave much less incorporation per OD 260 of ribo- somes used. Therefore, rabbit supernatants were used in most of the experiments to compare the capacities of ribosomes prepared from different subjects to incorporate amino acids.

c) Endogenous incorporation of the ribosomes of cells from thalassemic and nonthalassemic subjects. Ribosomes from cells of thalassemic subjects incorporated significantly less $(p=<0.01)$ ${ }^{14} \mathrm{C}$-radioactivity into protein per OD 260 of ribosomes compared to those of nonthalassemic subjects (Table II). This difference was observed when supernatant fractions prepared from cells from either nonthalassemic human subjects or rabbits were used. The endogenous amino acid incorporation, expressed per OD 260 of polyribosomes, was also markedly reduced in the thalassemic subjects. When valine- ${ }^{14} \mathrm{C}$, leucine $-{ }^{14} \mathrm{C}$, and phenylalanine $-{ }^{14} \mathrm{C}$ were used, the ribosome preparation from cells of nonthalassemic subjects incorporated, on the average, $5,800 \mathrm{cpm}$ per OD 260 of polyribosomes as compared to $1,300 \mathrm{cpm}$ per OD 260 with those of thalassemic subjects.

The possibility that the decreased capacity of thalassemic ribosomes to incorporate amino acids might be due to the presence of an inhibitor or the absence of an activator in the ribosome fractions was tested by the following experiments: Between 0.2 and 1.0 OD 260 of ribosomes from thalassemic and nonthalassemic subjects were mixed in varying ratios. Neither inhibition of the capacity of nonthalassemic ribosomes nor stimulation of the capacity of thalassemic ribosomes to incorporate amino acids into protein was detected (Table III). Two other experiments mixing ribosomes isolated from different subjects gave similar results. Su-

TABLE III

Effect on amino acid incorporation of mixing ribosomes from cells of thalassemic and nonthalassemic subjects*

\begin{tabular}{|c|c|c|c|}
\hline \multicolumn{2}{|c|}{ Ribosomes added } & \multicolumn{2}{|c|}{ Amino acid incorporated } \\
\hline $\begin{array}{l}\text { Thalas- } \\
\text { semic }\end{array}$ & $\begin{array}{c}\text { Nonthal- } \\
\text { assemic }\end{array}$ & Expected & Observed \\
\hline \multicolumn{2}{|c|}{$O D 260$} & & 150 \\
\hline 0.58 & $\begin{array}{l}0.54 \\
1.35\end{array}$ & & $\begin{array}{r}75 \\
770 \\
1740\end{array}$ \\
\hline 0.58 & 1.35 & 1,815 & 1,795 \\
\hline 0.92 & 0.54 & 890 & 850 \\
\hline
\end{tabular}

${ }^{*}$ Valine- ${ }^{14} \mathrm{C}$, leucine- ${ }^{14} \mathrm{C}$, and phenylalanine- ${ }^{14} \mathrm{C}$ were used in these experiments. The incubations were performed as described in Methods. 
pernate fractions prepared from thalassemic reticulocyte lysates did not inhibit amino acid incorporation when added to the complete cell free system containing either rabbit or normal human supernate with normal human ribosomes.

d) Poly $U$ responsiveness of the ribosomes of cells from thalassemic and nonthalassemic subjects. Studies were done to determine the capacity of ribosomes prepared from cells of thalassemic and nonthalassemic subjects to support poly U-directed incorporation of phenylalanine- ${ }^{-14} \mathrm{C}$ (Table IV). In the presence of poly $U$, ribosomes from thalassemic reticulocytes had levels of phenylalanine incorporation similar to those from nonthalassemic cells $(p=>0.05)$. In the absence of poly $U$, the phenylalanine incorporation of the thalassemic subjects was significantly lower than that of the nonthalassemic subjects $(\mathrm{p}=<$ 0.01).

To further test the possibility that there are functional differences between ribosomes prepared from thalassemic reticulocytes, we assayed the ribosomes under the following conditions. First, the activity of the ribosomes was examined by using different $\mathrm{Mg}^{++}$concentrations in the presence and absence of poly $U$. The optimal

\section{TABLE IV}

Polyuridylic acid-directed phenylalanine-14 $C$ incorporation with ribosomes from cells of nonthalassemic and thalassemic subjects*

\begin{tabular}{lll}
\hline Subject & No poly Ut & Poly U \\
\hline
\end{tabular}

cpm/OD 260 ribosomes

Nonthalassemic subjects

$\begin{array}{lll}\text { A.C. } & 685 & 18,800 \\ \text { K.N. } & 750 & 44,000 \\ \text { C.W. } & 368 & 12,200 \\ \text { S.C. } & 708 & 11,550 \\ \text { S.W. } & 350 & 19,600 \\ \text { O.A. } & 755 & 19,025\end{array}$

Average \pm SD $\quad 602 \pm 170 \quad 20,862 \pm 10,800$

\begin{tabular}{ccc}
\multicolumn{3}{c}{ Thalassemic subjects } \\
J.I. & 410 & 19,900 \\
F.P. & 257 & 27,300 \\
T.D. & 210 & 10,200 \\
M.D. & 150 & 9,750 \\
I.J. & 29 & 8,200 \\
N.G. & 450 & 14,600 \\
R.M. & 172 & 19,725 \\
S.C. & 200 & 10,100 \\
Average \pm SD & $235 \pm 128$ & $14,972 \pm 6,200$ \\
\hline
\end{tabular}

* Rabbit supernatants were used in these experiments.

$\dagger$ Poly $U$ = polyuridylic acid.
TABLE V

Ribosome content and polyribosome distribution in cells from nonthalassemic and thalassemic subjects

\begin{tabular}{|c|c|c|c|c|}
\hline Subject & $\begin{array}{l}\text { Reticulo- } \\
\text { cyte } \\
\text { count }\end{array}$ & $\begin{array}{c}\text { Polyri- } \\
\text { bosomes* }\end{array}$ & $\begin{array}{c}\text { Ribosome } \\
\text { content }\end{array}$ & $\begin{array}{l}\text { Polyri- } \\
\text { bosome } \\
\text { content }\end{array}$ \\
\hline & $\%$ & $\%$ & \multicolumn{2}{|c|}{$\begin{array}{l}\text { OD } 260 / 10^{10} \\
\text { reticulocytes }\end{array}$} \\
\hline \multicolumn{5}{|c|}{ Nonthalassemic subjects } \\
\hline K.N. & 31 & 40 & 23 & 9.2 \\
\hline B.B & 30 & 40 & 18 & 7.2 \\
\hline S.W. & 6 & 50 & 23 & 11.5 \\
\hline O.A. & 12 & 50 & 38 & 19.0 \\
\hline S.C. & 8 & 60 & 11 & 6.6 \\
\hline A.C. & 92 & 30 & 14 & 4.2 \\
\hline K.R. & 11 & 30 & 6 & 1.8 \\
\hline D.N. & 25 & 50 & 28 & 14.0 \\
\hline V.M. & 20 & 50 & & \\
\hline Y.M. & 17 & & 19 & \\
\hline Average $\pm S D$ & $23 \pm 24$ & $43 \pm 10$ & $20 \pm 8$ & $9.2 \pm 5.2$ \\
\hline \multicolumn{5}{|c|}{ Thalassemic subjects } \\
\hline S.C. & 4 & 15 & 40 & 6.0 \\
\hline F.Z. & 9 & 25 & 56 & 14.0 \\
\hline A.G. & 3 & 25 & & \\
\hline G.S. & 4 & 15 & 38 & 5.7 \\
\hline N.G. & 9 & 20 & 34 & 6.8 \\
\hline R.M. & 12 & 20 & 31 & 6.2 \\
\hline J.I. & 5 & 20 & 11 & 2.2 \\
\hline J.P. & 9 & 20 & 16 & 3.2 \\
\hline T.D. & 6 & 20 & 54 & 10.8 \\
\hline A.A. & 3 & & 41 & \\
\hline J.M. & 4 & & 15 & \\
\hline Z.T. & 4 & & 22 & \\
\hline Average $\pm \mathrm{SD}$ & $5 \pm 3$ & $20 \pm 3$ & $33 \pm 13$ & $7.0 \pm 4.2$ \\
\hline
\end{tabular}

* Methods of analyses employed to determine polyribosomes, ribosomes, and reticulocyte count are detailed in Methods.

$\mathrm{Mg}^{++}$concentration for ribosomes of both thalassemic and nonthalassemic cells was 12 mmoles per $\mathrm{L}$ with poly U. Second, leucine $-{ }^{14} \mathrm{C}$ incorporation in the presence of poly $U$ was used to test for possible ambiguous coding at high magnesium concentrations (18). With ribosomes from both thalassemic and nonthalassemic cells, the only effect noted was inhibition by poly $U$ of endogenous leucine- ${ }^{14} \mathrm{C}$ incorporation at magnesium concentrations between 7 and 20 mmoles per L.

e) Ribosome and polyribosome content of erythroid cells. The ribosome content of the cells was, on the average, 33 OD 260 per $10^{10}$ reticulocytes in subjects with thalassemia and 20 OD 260 per $10^{10}$ reticulocytes in nonthalassemic subjects ( $\mathrm{Ta}$ ble $\mathrm{V})$. The differences between these values are not significant at the $2 \%$ level $(p=>0.02$ and $<0.05)$. The proportion of the ribosomes that was polyribosomes differed significantly $(\mathrm{p}=<$ 0.01 ) in the two groups. The proportion of polyribosomes in cells of subjects with thalassemia 


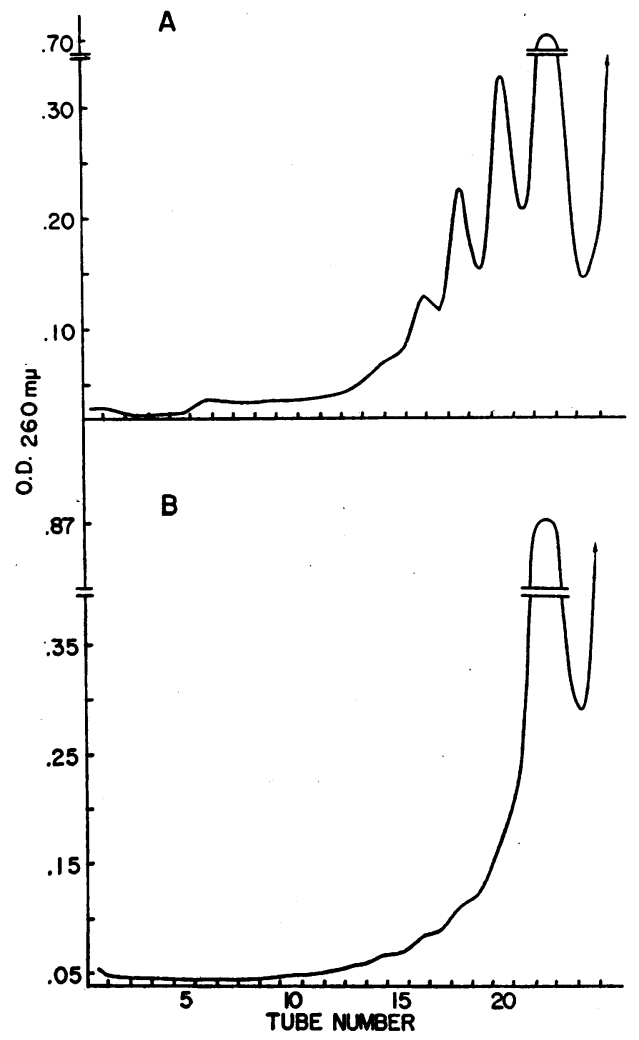

Fig. 1. Patterns of Sedimentation of Ribosomes ANALYZED BY THE METHOD OF SUCROSE DENSITY GRADIENT CENTRIFUGATION. A) 2.5 OD 260 of ribosomes prepared from the cells of nonthalassemic subject B.B. (Table V) were layered on $26 \mathrm{ml}$ of a 15 to $30 \%$ linear sucrose gradient in a solution of $0.01 \mathrm{M} \mathrm{KCl}, 0.0015 \mathrm{M} \mathrm{MgCl}$, and $0.001 \mathrm{M}$ Tris $\mathrm{HCl}$ buffer, $\mathrm{pH}$ 7.4. Centrifugation was at $25,000 \times g$ for 28 hours at $4^{\circ}$ in a Spinco SW 25.1 rotor. B) $2.0 \mathrm{OD} 260$ of ribosomes prepared from the cells of thalassemic subject F.Z. (Table V) were similarly treated.

averaged $20 \%$, whereas that in cells of nonthalassemic subjects averaged $43 \%$. Typical patterns of sedimentation obtained after the sucrose gradient density centrifugation of ribosomes from the cells of nonthalassemic and thalassemic subjects are shown in Figure 1. Multiplying the ribosome content by the per cent polyribosomes (see Table V) yielded values for the polyribosome content per $10^{10}$ reticulocytes. When this calculation was employed, the polyribosome content of cells from thalassemic and nonthalassemic subjects did not differ significantly $(p=>0.20)$. The polyribosome content of cells from thalassemic subjects averaged 9.2 OD 260 per $10^{10}$ reticulocytes, whereas that of cells from nonthalassemic subjects averaged 7.0 OD 260 per $10^{10}$ reticulocytes.

There seemed to be a poor correlation between the proportion of red blood cells that was reticulocytes and the ribosome or polyribosome content per reticulocyte (Table V). In studies with rabbit red cells (10) it was similarly observed that the degree of reticulocytosis did not correlate well with the ribosome or polyribosome content of the cells or the capacity of the cells to synthesize protein. The ability of rabbit reticulocytes to synthesize proteins is closely related to the polyribosome content of these cells.

\section{Discussion}

Theories attempting to explain the defect in thalassemia have focused on mechanisms by which the rate of globin chain synthesis might be diminished. It has been suggested that a defective regulatory gene might be responsible $(2,3)$. Alternatively, Itano has proposed that a supernatant factor such as a specific amino-acyl transfer RNA (sRNA) might be rate limiting (19). Previous studies from this laboratory $(5,6)$ suggested that the defect may be at the level of the ribosome-mRNA complex. This latter hypothesis is supported by the present demonstration of a markedly decreased endogenous capacity of ribosomes of thalassemic cells to incorporate amino acids in the cell free system. In addition, the inability of supernatant fractions prepared from cells of nonthalassemic subjects or from rabbit reticulocytes (see Table II) to correct the low endogenous activity of ribosomes from thalassemic cells is consistent with a defect in the ribosome-mRNA complex rather than a soluble supernatant factor such as an enzyme or sRNA.

There is no significant difference in the capacities of ribosomes prepared from cells of nonthalassemic and thalassemic subjects to respond to poly U-directed phenylalanine incorporation, and to incorporate amino acids under various conditions of $\mathrm{Mg}^{++}$concentration. These data imply that in thalassemia the ribosomes per se may not be defective; on the other hand, the conditions under which the ribosomes respond to poly $U$ may be different from those required for stimulation by natural mRNA. It is currently believed that ribosomes are necessary for the synthesis of all pro- 
teins (20). Since in thalassemic cells the impairment in protein synthesis is selective for hemoglobin A synthesis, the integrity of the ribosomes and their responsiveness to synthetic mRNA might be expected. Taken together, the present evidence leads us to focus on a decreased or altered mRNA for hemoglobin $\mathrm{A}$ as the molecular basis for the defect in thalassemia. It has been suggested that a strand of mRNA holds the polyribosome complex together (20-24). If this is true, then the fact that the endogenous incorporation per OD 260 of polyribosomes is significantly decreased in the thalassemic cells may indicate that this mRNA is relatively inactive or abnormal in these cells. The abnormality in mRNA could be such as to lead to a decreased rate of formation of structurally normal hemoglobin A. Alternatively, polyribosomes may be held together by a structure other than mRNA and the present findings can be explained by a decreased amount of mRNA for hemoglobin A in thalassemic cells.

The decreased capacity of ribosome fractions of cells from subjects with thalassemia major to incorporate amino acids could reflect the fact that the reticulocytes in thalassemia represent an older population of cells than those of the control group. This seems unlikely on the basis of several considerations. First, thalassemia major generally represents a chronic hemolytic state with as marked erythroid hyperplasia as that encountered in any of the chronic hemolytic anemias to which it is being compared (25). Second, the ribosome and polyribosome content per reticulocyte is not significantly different in the cells of thalassemic and nonthalassemic subjects. These findings suggest strongly that the two groups of reticulocytes are comparable in age. In rabbits, it has been demonstrated that the maturation of reticulocytes is associated with a decrease in the polyribosome and ribosome content per cell $(15,26)$. The stage of maturation of the rabbit reticulocytes correlated well with the ribosome content of the cells. Third, evidence has recently been presented that reticulocytes of thalassemic subjects might be, on the average, a population of younger cells (27) when compared with other chronic hemolytic anemias.

\section{Summary}

A cell free system for protein synthesis has been developed from peripheral erythroid cells of human subjects with thalassemia major and with other chronic hemolytic anemias. The endogenous capacity to incorporate amino acids of ribosomes prepared from cells of thalassemic subjects is markedly diminished compared to that of nonthalassemic subjects. The ability of the ribosomes to respond to polyuridylic acid-directed phenylalanine incorporation is comparable for both groups. The defect in endogenous activity of ribosomes from cells of thalassemic subjects is not corrected in the cell free system by the addition of supernatant fractions prepared from cells of nonthalassemic subjects or from rabbit reticulocytes. It is suggested that the primary defect in thalassemia major involves a decrease or defect in messenger RNA for hemoglobin A.

\section{Acknowledgments}

We appreciate the excellent technical assistance of Sung Paik. We are deeply grateful to Drs. James Wolff of the Presbyterian Hospital, Marion Erlandson of New York Hospital, and Janet Watson of Kings County Hospital and their colleagues for permitting us to study these patients.

\section{References}

1. Rich, A. Studies on the hemoglobin of Cooley's anemia and Cooley's trait. Proc. nat. Acad. Sci. (Wash.) 1952, 38, 187.

2. Itano, H. A. The human hemoglobins: their properties and genetic control. Advanc. Protein Chem. 1957, 12, 215.

3. Ingram, V. M., and A. O. W. Stretton. Genetic basis of the thalassæmia diseases. Nature (Lond.) 1959, 184, 1903.

4. Guidotti, G., referred to by V. M. Ingram. The Hemoglobins in Genetics and Evolution. New York, Columbia University Press, 1963, p. 116.

5. Burka, E. R., and P. A. Marks. Ribosomes active in protein synthesis in human reticulocytes: a defect in thalassæmia major. Nature (Lond.) 1963, 199, 706.

6. Marks, P. A., and E. R. Burka. Hemoglobins A and $F$. Formation in thalassemia and other hemolytic anemias. Science 1964, 144, 552.

7. Borsook, H., E. H. Fischer, and G. Keighley. Factors affecting protein synthesis in vitro in rabbit reticulocytes. J. biol. Chem. 1957, 229, 1059.

8. Weisberger, A. S., S. Armentrout, and S. Wolfe. Protein synthesis by reticulocyte ribosomes. I. Inhibition of polyuridylic acid-induced ribosomal protein synthesis by chloramphenicol. Proc. nat. Acad. Sci. (Wash.) 1963, 50, 86. 
9. Britten, R. J., and R. B. Roberts. High-resolution density gradient sedimentation analysis. Science 1960, 131, 32.

10. Rifkind, R. A., D. Danon, and P. A. Marks. Alterations in polyribosomes during erythroid cell maturation. J. Cell Biol. 1964, 22, 599.

11. Allen, E. H., and R. S. Schweet. Synthesis of hemoglobin in' a cell-free system. I. Properties of the complete system. J. biol. Chem. 1962, 237, 760.

12. Wolfe, S. M., and A. S. Weisberger. Protein synthesis by reticulocyte ribosomes. II. The effects of magnesium ion and chloramphenicol on induced protein synthesis. Proc. nat. Acad. Sci. (Wash.) 1965, 53, 991.

13. Revel, J., and $H$. H. Hiatt. Magnesium requirement for the formation of an active messenger RNA-ribosome-sRNA complex. J. molec. Biol. 1965, 11, 467.

14. Bray, G. A. A simple efficient liquid scintillator for counting aqueous solutions in a liquid scintillation counter. Analyt. Biochem. 1960, 1, 279.

15. Ott, D. G., C. R. Richmond, T. T. Trujillo, and H. Foreman. Cab-O-Sil suspensions for liquid-scintillation counting. Nucleonics 1959, 17, 106.

16. Lindquist, E. F. A First Course in Statistics. Boston, Houghton Mifflin, 1942, p. 897.

17. Necheles, T. F., M. Steiner, and M. Baldini. The in vitro synthesis of hemoglobin by human bone marrow in thalassemia. Blood 1965, 25, 897.

18. Davies, J., W. Gilbert, and L. Gorini. Streptomycin, suppression, and the code. Proc. nat. Acad. Sci. (Wash.) 1964, 51, 883.
19. Itano, H. A., referred to by E. R. Huehns and E. M. Shooter. Human hemoglobins. J. med. Genet. 1965, 2, 1.

20. Watson, J. D. Involvement of RNA in the synthesis of proteins. The ordered interaction of three classes of RNA controls the assembly of amino acids into proteins. Science 1963, 140, 17.

21. Gilbert, W. Polypeptide synthesis in Escherichia coli. II. The polypeptide chain and S-RNA. J. molec. Biol. 1963, 6, 389.

22. Gierer, A. Function of aggregated reticulocyte ribosomes in protein synthesis. J. molec. Biol. 1963, 6, 148.

23. Warner, J. R., P. M. Knopf, and A. Rich. A multiple ribosomal structure in protein synthesis. Proc. nat. Acad. Sci. (Wash.) 1963, 49, 122.

24. Wettstein, F. O., T. Staehelin, and M. Noll. Ribosomal aggregate engaged in protein synthesis: characterization of the ergosome. Nature (Lond.) 1964, 197, 430.

25. Gabuzda, T. G., D. G. Nathan, and F. H. Gardner. The turnover of hemoglobins $\mathrm{A}, \mathrm{F}$, and $\mathrm{A}_{2}$ in the peripheral blood of three patients with thalassemia. J. clin. Invest. 1963, 42, 1678.

26. Glowacki, E. R., and R. L. Millette. Polyribosomes and the loss of hemoglobin synthesis in the maturing reticulocyte. J. molec. Biol. 1965, 11, 116.

27. Eylar, E. H., and G. T. Matioli. Glycoprotein biosynthesis in human reticulocytes: a lesion in thalassemia. Science 1965, 147, 869. 